\title{
Brain-Derived Neurotrophic Factor Increases in the Uninjured Dorsal Root Ganglion Neurons in Selective Spinal Nerve Ligation Model
}

\author{
Tetsuo Fukuoka, Eiji Kondo, Yi Dai, Norio Hashimoto, and Koichi Noguchi \\ Department of Anatomy and Neuroscience, Hyogo College of Medicine, 1-1 Mukogawa-cho, Nishinomiya, Hyogo 663- \\ 8501, Japan
}

Nerve growth factor (NGF) and brain-derived neurotrophic factor (BDNF) are two major members of the neurotrophin family. Using immunohistochemistry and in situ hybridization histochemistry, we examined the effect of L5 spinal nerve ligation (SPNL), a neuropathic pain model, on the expression of BDNF in the uninjured L4 dorsal root ganglion (DRG). After L5 SPNL, both immunoreactivity for BDNF and the hybridization intensity for BDNF mRNA increased mainly in the small- and mediumsized neurons. The percentage of BDNF mRNA-expressing neurons increased in the ipsilateral L4 DRG compared with the contralateral DRG from the third to 28th day after ligation. A significantly greater number of BDNF-immunoreactive neurons were observed in the ipsilateral L4 DRG than contralateral side $14 \mathrm{~d}$ after ligation. To test the contribution of BDNF to the thermal hyperalgesia produced in this model, we intrathecally injected anti-BDNF antibody at third day after ligation. This treatment clearly attenuated thermal hyperalgesia for a few hours. Almost all BDNF mRNA-expressing neurons coexpressed trkA, a high-affinity NGF receptor, mRNA. The percentage of BDNF mRNA-expressing cells of trkA cells significantly increased in the ipsilateral L4 DRG $14 \mathrm{~d}$ after ligation. Further- more, we examined the contribution of NGF on this phenotypic change using ELISA, Northern blot analysis, and anti-NGF antibody. NGF content in the ipsilateral L4 DRG linearly increased and reached a statistical significant level $14 \mathrm{~d}$ after L5 SPNL. Moreover, at this time point, the increase in NGF mRNA was observed in the ipsilateral L5 DRG and sciatic nerve, but not in the ipsilateral L4 DRG or L4 spinal nerve. Local application of anti-NGF antibody to the L4 spinal nerve beside the L5 spinal nerve-ligation site prevented the development of thermal hyperalgesia for $5 \mathrm{~d}$ after ligation. Our data suggest that BDNF, which increased in the uninjured L4 DRG neurons, acts as a sensory neuromodulator in the dorsal horn and contributes to thermal hyperalgesia in this neuropathic pain model. The contribution of locally synthesized NGF to thermal hyperalgesia was also demonstrated. These dynamic alterations in the expression and content of BDNF and NGF in the uninjured DRG neurons might be involved in the pathomechanisms of neuropathic pain.

Key words: BDNF; NGF; trkA; thermal hyperalgesia; dorsal root ganglion; neuropathic pain model
The phenotypic change of dorsal root ganglion (DRG) neurons has been extensively studied as an explanation for neuropathic pain that occurs after peripheral nerve injury. The axotomized neurons increase or decrease their expression of a variety of molecules, such as neuropeptides, receptors, and ion channels. Some of these phenotypic changes may contribute to development and maintenance of spontaneous pain and may have roles in central sensitization in the spinal cord. However, it is certain that evoked pain by natural stimuli applied to the periphery must be transferred by the neurons spared from axotomy, because the axotomized neurons are no longer capable of responding to the peripheral stimuli. The plantar surface of the rat hindpaw is innervated by the L3-L5 spinal nerves (Takahashi et al., 1994). Among the three major neuropathic foot plantar pain models in

Received Feb. 13, 2001; revised April 3, 2001; accepted April 12, 2001.

This work was supported by Grants-in-Aid for Science Research from the Japanese Ministry of Education, Science and Culture, and Health Sciences Research Grant (Comprehensive Research on Aging and Health) from the Japanese Ministry of Health and Welfare. We thank Amgen, Inc. for providing the anti-BDNF antibody. We gratefully acknowledge technical assistance from Masako Tatsumi, Yuko Shimada, and Yuri Seki.

Correspondence should be addressed to Tetsuo Fukuoka, Department of Anatomy and Neuroscience, Hyogo College of Medicine, 1-1 Mukogawa-cho, Nishinomiya, Hyogo 663-8501, Japan. E-mail tfukuoka@hyo-med.ac.jp.

Copyright (C) 2001 Society for Neuroscience $0270-6474 / 01 / 214891-10 \$ 15.00 / 0$ rats (Bennett and Xie, 1988; Seltzer et al., 1990; Kim and Chung, 1992), the L5 and L6 spinal nerve ligation (SPNL) model (Kim and Chung, 1992) is unique because the uninjured L4 DRG neurons are clearly separated from the axotomized L5 and L6 DRG neurons. Thus, the L4 spinal nerve should be the main route through which the impulses evoked in the periphery are transferred to the spinal dorsal horn in this model (Li et al., 2000). Therefore, we focused the phenotypic change of the L4 DRG neurons using the more simplified L5 SPNL model.

Brain-derived neurotrophic factor (BDNF) is a type of neurotrophin, which has been studied in terms of the roles in neuronal survival and development. Recently, much attention has focused on the role of BDNF as a new neuromodulator in the spinal dorsal horn, especially in inflammatory pain states (Kerr et al., 1999; Mannion et al., 1999; Thompson et al., 1999). The contribution of BDNF to the pathophysiological mechanism of neuropathic pain has not yet been examined. In this study, we investigated BDNF expression in the L4 DRG after L5 SPNL using in situ hybridization histochemistry and immunohistochemistry. In previous studies (Fukuoka et al., 1998a,b), we demonstrated that the expression of calcitonin gene-related peptide (CGRP) mRNA and preprotachykinin (PPT; a gene encoding substance P) mRNA increased in a subpopulation of the neurons in the ipsilateral L4 DRG after L5 SPNL. Ma and Bisby (1998) demon- 
strated that substance $\mathrm{P}$ expression increased in spared DRG neurons $14 \mathrm{~d}$ after chronic constriction injury of the sciatic nerve (Ma and Bisby, 1998). Because BDNF expression in DRG is known to be regulated by nerve growth factor (NGF) as well as CGRP and PPT (Apfel et al., 1996; Cho et al., 1997; Michael et al., 1997), we examined coexpression of BDNF mRNA with trkA mRNA and measured the content of NGF protein and mRNA in the L4 DRG, L4 spinal nerve, and sciatic nerve using this model. Furthermore, we tested whether anti-BDNF and anti-NGF antibodies could reverse thermal hyperalgesia and influence the increase in BDNF expression.

Preliminary results from this study have been published in abstract form (Fukuoka et al., 2000).

\section{MATERIALS AND METHODS}

Animal model. All animal experiments conformed to the regulations of the Hyogo College of Medicine Committee on Animal Research and were performed in accordance with the guidelines of the National Institutes of Health on animal care.

A total of 116 male Sprague Dawley rats, weighing 170-270 gm (250-270 gm for the intrathecal injection study and 170-200 gm for the other studies), were used. All surgical procedures were done on rats that were deeply anesthetized with sodium pentobarbital $(50 \mathrm{mg} / \mathrm{kg}$ body weight, i.p.). Additional doses of the anesthetics were given as needed. L5 spinal nerve ligation was performed on 76 rats. The surgeries were performed with some modifications to the original SPNL model (Kim and Chung, 1992). Special attention was paid to prevent infection, thus minimizing the influence of inflammation. Briefly, the hair of the lower back of the rats was shaved and the skin was sterilized with $0.5 \%$ chlorhexidine and covered with clean paper. Using sterilized operating instruments, the left L5 spinal nerve ( $\mathrm{SpN})$ was isolated and tightly ligated with 3-0 silk thread (L5 SPNL). In sham-operated rats $(n=20)$, the left L5 spinal nerve was isolated, without ligation. The right side was not subjected to any surgery in both groups. The wound was washed with $5 \mathrm{ml}$ of distilled saline and sutured with 3-0 silk thread. The remaining 20 rats were used as naive controls in the Northern blot and ELISA.

Behavioral tests. The tests for mechanical allodynia and heat hyperalgesia of the plantar surface of the hindpaws were done in all rats $1 \mathrm{~d}$ before surgery and 1, 3, 5, 7, 10, and $14 \mathrm{~d}$ after surgery until killing. The frequency of the paw withdrawal in response to normally innocuous mechanical stimuli was measured using a von Frey filament of $72.2 \mathrm{mN}$. The rat was placed on a metal mesh floor covered with an inverted clear plastic cage $(18.5 \times 9 \times 14.5 \mathrm{~cm})$. The von Frey filament was then applied from underneath the metal mesh floor to the plantar surface of the paw. The von Frey filament was applied to each paw for five trials (six applications of $3 \mathrm{sec} /$ trial). The occurrence of paw withdrawals was expressed as "response frequency" (i.e., number of trials accompanied by paw withdrawal $/ 5 \times 100)$.

Heat hypersensitivity was tested using the plantar test (Ugo Basile, Varese, Italy). Specifically, the rat was placed beneath the same plastic cage used for the mechanical allodynia test, but this time on an elevated glass floor. With the rat standing relatively still, a radiant heat source beneath the glass floor was aimed at the plantar surface of the hindpaw. The withdrawal latency was measured to the nearest $0.1 \mathrm{sec}$. Before assessment of heat hyperalgesia, the intensity of the radiant heat source was adjusted to yield a mean baseline latency of $\sim 10 \mathrm{sec}$ from five naive rats with the cutoff automatically set at $22.5 \mathrm{sec}$ to avoid tissue damage. The hindpaws were tested alternately with $>5$ min intervals between consecutive tests. Three latencies were taken for each hindpaw in each test session. The three latencies per side were averaged, and a difference score was computed by subtracting the average latency of the contralateral side from that of the ipsilateral side. Negative difference scores indicated a hyperalgesic response on the ipsilateral side.

Data are were expressed as mean \pm SEM. Differences in changes of values over time were tested using one-way repeated measures ANOVA. The difference between each time point was tested by Fisher's protected least significant difference (PLSD) test. Two-tailed $p$ values $<0.05$ were considered to be significant.

Immunohistochemistry. For immunohistochemistry, four rats that received L5 SPNL 14 d before were used. These rats were deeply anesthetized with sodium pentobarbital ( $70-80 \mathrm{mg} / \mathrm{kg}$ body weight, i.p.) and perfused transcardially with $100 \mathrm{ml}$ of $1 \%$ paraformaldehyde in $0.1 \mathrm{M}$ phosphate buffer (PB), pH 7.4, followed by $500 \mathrm{ml}$ of $4 \%$ paraformaldehyde in $0.1 \mathrm{M}$ PB. The L4 DRG was dissected out and post-fixed in the same fixative for $4 \mathrm{hr}$ at $4^{\circ} \mathrm{C}$, followed by immersion in $20 \%$ sucrose in 0.1 $\mathrm{M} \mathrm{PB}$ at $4^{\circ} \mathrm{C}$ overnight for cryoprotection. The tissue was frozen in powdered dry ice, cut on a cryostat at $30 \mu \mathrm{m}$ thickness, and placed in 0.1 M PBS.

The floating sections were preincubated in PBS containing $10 \%$ normal goat serum (NGS) and $0.3 \%$ Triton X-100 for $1 \mathrm{hr}$, then incubated in primary antibody in the same solution for $48 \mathrm{hr}$ at $4^{\circ} \mathrm{C}$. Rabbit antiBDNF polyclonal antiserum was used (a kind gift from Amgen, Thousand Oaks, CA; $1 \mu \mathrm{g} / \mathrm{ml})$. The sections were washed in PBS and then incubated in biotinylated anti-rabbit IgG (1:200; Vector Laboratories, Burlingame, CA) in PBS containing 5\% NGS for $2 \mathrm{hr}$ at $4^{\circ} \mathrm{C}$, followed by incubation in avidin-biotin-peroxidase complex (Elite ABC kit; Vector) for $1 \mathrm{hr}$ at room temperature. The horseradish peroxidase reaction was developed in $0.1 \mathrm{M}$ Tris-buffered saline, $\mathrm{pH} 7.4$, containing $0.05 \% 3,3^{\prime}$ diaminobenzidine tetrahydrochloride (Sigma, Steinheim, Germany), $0.3 \%$ nickel sulfate, and $0.01 \%$ hydrogen peroxidase. Sections were then washed in PBS, mounted on slides, dried, and coverslipped.

In situ hybridization histochemistry. For in situ hybridization histochemistry (ISHH), the rats were killed by decapitation under deep anesthesia (70-80 $\mathrm{mg} / \mathrm{kg}$ body weight, i.p.) 1, 3, 7, 14, and $28 \mathrm{~d}$ after L5 SPNL and $14 \mathrm{~d}$ after the sham operation ( $n=4$ at each time point). Bilateral L4 and L5 DRGs were dissected out, rapidly frozen in powdered dry ice, and cut on a cryostat at a $16 \mu \mathrm{m}$ thickness for standard ISHH or at a $6 \mu \mathrm{m}$ thickness for ISHH on the serial sections. Sections from four DRGs of each rat were thaw-mounted onto eight slides coated with silane (3aminopropyl triethoxysilane) for standard ISHH or onto 10 pairs of slides for ISHH for the serial sections, and stored at $-80^{\circ} \mathrm{C}$ until use.

Oligonucleotide probes complementary to bases 156-204 of the rat BDNF sequence (Maisonpierre et al., 1991; GenBank accession number M61175), bases 1184-1231 (Kashiba et al., 1995) of the rat trkA sequence (Meakin et al., 1992; GenBank accession number M85214), and bases 868-918 (Wetmore et al., 1990) of rat $\beta$ NGF sequence (Whittemore et al., 1988; GenBank accession number M36589) were synthesized. The specificity of these three probes was confirmed by Northern blot analysis, as described below (Fig. 1). These probes were labeled with ${ }^{35} \mathrm{~S}$ deoxyadenosine triphosphate (NEN, Boston, MA) and terminal deoxynucleotidyl transferase (Amersham Pharmacia Biotech, Arlington Heights, IL), giving a specific activity of $1.0-1.5 \times 10^{9} \mathrm{cpm} / \mathrm{mg}$. Sections were hybridized after thawing, without any pretreatment, overnight at $42^{\circ} \mathrm{C}$ in humidified boxes with $5 \times 10^{5} \mathrm{cpm}$ of labeled probe per $100 \mu \mathrm{l}$ of a mixture containing $4 \times \mathrm{SSC}(1 \times \mathrm{SSC}=0.15 \mathrm{~mm} \mathrm{NaCl}$ and $0.015 \mathrm{~mm}$ sodium citrate), $50 \%$ formamide, $0.12 \mathrm{M}$ phosphate buffer, $1 \times$ Denhardt's solution, $0.2 \%$ SDS, $250 \mu \mathrm{g} / \mathrm{ml}$ yeast tRNA, $10 \%$ dextran sulfate, and 100 $\mathrm{mM}$ dithiothreitol. After hybridization, the sections were rinsed four times each for $15 \mathrm{~min}$ at $55^{\circ} \mathrm{C}$ in $1 \times \mathrm{SSC}$, dipped in distilled water, transferred through 60,80 , and $95 \%$ ethanol, and then air-dried. For autoradiography, the sections were coated with NTB-3 emulsion (Kodak, Rochester, NY; diluted $2: 3$ with distilled water at $45^{\circ} \mathrm{C}$ ) and exposed in light-tight boxes at $4^{\circ} \mathrm{C}$ for 3-4 weeks. After development in D19 (Kodak) and fixation in $24 \%$ sodium thiosulfate, the sections were rinsed in distilled water, counterstained with neutral red, dehydrated in a graded ethanol series, cleared in xylene, and coverslipped.

Quantitative analysis. Measurements of the density of silver grains over randomly selected tissue profiles were performed using a computerized image analysis system (NIH Image, version 1.61) by a blinded assistant, where only neuronal profiles that contained nuclei were used for quantification. At a magnification of $200 \times$ and with bright-field illumination, upper and lower thresholds of gray level density were set such that only silver grains were accurately discriminated from the background in the outlined cell or tissue profile and read by the computer pixel-by-pixel. Subsequently, the area of discriminated pixels was measured and divided by the area of the outlined profile, giving a grain density for each cell or tissue profile. To reduce the risk of biased sampling of the data because of varying emulsion thickness, we used a signal-to-noise $(\mathrm{S} / \mathrm{N})$ ratio for each cell in each tissue. The $\mathrm{S} / \mathrm{N}$ ratio of an individual neuron and its cross-sectioned area, which was computed from the outlined profile, was plotted. Based on this scattergram, neurons with a grain density of twofold the background level or higher $(2 \leq \mathrm{S} / \mathrm{N}$ ratio) were considered positively labeled for BDNF mRNA. To distinguish cell size-specific changes, we characterized the DRG neurons as small $\left(<600 \mu \mathrm{m}^{2}\right)$-, medium $\left(600-1200 \mu \mathrm{m}^{2}\right)$-, and large $\left(>1200 \mu \mathrm{m}^{2}\right)$-sized neurons, according to their cross-sectional area. Because a stereological approach 
was not used in this study, quantification of the data may represent a biased estimate of the actual numbers of neurons.

At least 250 neurons from each L4 DRG of each rat were measured. The number of positively labeled DRG neurons was divided by the number of neuronal profiles counted in each DRG. Data are expressed throughout as mean \pm SEM $(\%)$. Pairwise comparisons $(t$ test $)$ were used to assess differences of values between ipsilateral and contralateral DRGs. Two-tailed $p$ values of $<0.05$ were considered to be significant.

Intrathecal injection of anti-BDNF antibody. Under adequate anesthesia with sodium pentobarbital, the rats Th11 vertebra were laminectomized. A soft tube (Silascon, Kaneka Medix Company, Osaka, Japan; outer diameter, $0.64 \mathrm{~mm}$ ) was inserted into the subarachnoid space for an $\sim 1.5$ $\mathrm{cm}$ length to ensure that the tip reached to the lumbar enlargement. Three days later, the rats received L5 SPNL as described above. All rats that showed motor impairment were excluded. After an additional $3 \mathrm{~d}$, the development of neuropathic pain was confirmed, and sheep antiBDNF antibody (20 $\mu \mathrm{g}$ in $20 \mu \mathrm{l}$ of PBS; Chemicon, Temecula, CA) or normal sheep IgG $(20 \mu \mathrm{g}$ in $20 \mu \mathrm{l}$ of PBS; Cappel, Aurora, OH) was injected through the intrathecal cannula. The pain response to radiant heat was tested as described above at 1, 2.5, 4, 6, and $12 \mathrm{hr}$ after injection.

Northern blot analysis. Sixteen rats were deeply anesthetized with sodium pentobarbital $(70-80 \mathrm{mg} / \mathrm{kg}$ body weight, i.p.) and killed by decapitation $14 \mathrm{~d}$ after L5 SPNL. The survival time of $14 \mathrm{~d}$ was selected because NGF content in the ipsilateral L4 DRG was significantly increased at this time point (see Results). The L4 and L5 DRG, L4 spinal nerves, and sciatic nerves were rapidly removed and immediately frozen on dry ice and stored at $-80^{\circ} \mathrm{C}$. To obtain enough total RNA, each sample contained tissue from four rats. Therefore, four pooled samples were independently measured for NGF mRNA expression. In addition, four naive rats were used to confirm the specificity of the oligonucleotide probes. The extraction of total RNA was performed using the RNA extraction regent Isogen (Nippon Gene, Tokyo, Japan). Briefly, the sample was homogenized in $1 \mathrm{ml}$ of Isogen regent, mixed with $200 \mu \mathrm{l}$ of chloroform, and centrifuged for $15 \mathrm{~min}$ at $4^{\circ} \mathrm{C}$ and $12000 \mathrm{G}$. The supernatant was mixed with the same volume of isopropyl alcohol and centrifuged again under the same conditions. The precipitate was washed in $75 \%$ ethanol and air-dried. Twenty micrograms of RNA were fractionated by electrophoresis through a $1 \%$ agarose/formaldehyde gel and transferred overnight to a Hybond-N membrane (Amersham) in $20 \times$ SSC. After UV cross-linking and baking for $1 \mathrm{hr}$ at $80^{\circ} \mathrm{C}$, the membranes were prehybridized with $10 \mathrm{ml}$ of hybridization buffer $(50 \%$ formamide, $3.6 \times$ SSPE, $1 \%$ SDS, $5 \times$ Denhardt's solution, and $0.1 \mathrm{mg} / \mathrm{ml}$ salmon sperm DNA) in glass bottles for $6 \mathrm{hr}$ at $42^{\circ} \mathrm{C}$, then the labeled oligonucleotide probes were added into the bottles and hybridized overnight at $42^{\circ} \mathrm{C}$. The oligonucleotide probes were labeled with ${ }^{32} \mathrm{P}$-deoxyadenosine triphosphate (NEN) and terminal deoxynucleotidyl transferase (Amersham), giving a specific activity of $3-6 \times 10^{9} \mathrm{cpm} / \mathrm{mg}$. After hybridization, the membranes were washed three times in $50 \mathrm{ml}$ of $2 \times$ SSC at room temperature, followed by washing in $300 \mathrm{ml}$ of $2 \times$ SSC containing $0.1 \%$ SDS for $30 \mathrm{~min}$ at $65^{\circ} \mathrm{C}$. Kodak BioMax film was used with Kodak intensifying screens for the autoradiograms. The film was developed and fixed using Konica SRX-101 autodeveloper.

Each of the newly designed oligonucleotide probes showed one or two bands at the positions expected from previous studies (BDNF, 1.6-1.8 kb and 4.2-4.4 kb; trkA, $3.2 \mathrm{~kb}$; $\beta$ NGF, $1.4 \mathrm{~kb}$ ) (Fig. 1) (Schwartz, 1988; Ernfors et al., 1993; Mannion et al., 1999).

The expression of $\beta$ NGF mRNA was quantified using the gel-plotting macros of NIH Image, version 1.61. A 40 mer oligonucleotide probe for glyceraldehyde-3-phosphate (GAPDH; Oncogene Research Products) was used as an internal control. Four independent blottings were performed and measured. The expression on the ipsilateral side is presented as mean \pm SEM $(\%)$ of contralateral side. Differences from $100 \%$ were tested using $t$ tests. Two-tailed $p$ values $<0.05$ were considered to be significant.

NGF ELISA. NGF concentration was measured using a two-site (Sandwich) ELISA based on a protocol provided by Boehringer Mannheim (Indianapolis, IN). The first antibody was a monoclonal anti-mouse $\beta$ NGF antibody (clone 27/21; Boehringer Mannheim), and the second antibody was the same antibody conjugated with $\beta$-galactosidase.

L4 DRG, L4 SpN, and sciatic nerve $(\mathrm{ScN})$ were collected from 16 naive rats, 16 sham-operated rats, and the rats that received L5 SPNL 1, 4, 7, and $14 \mathrm{~d}$ before (16 rats at each time point). To obtain detectable NGF protein, each sample contained tissue from four rats. Therefore, four samples were measured for each time point. Each sample was weighed and homogenized in $200 \mu \mathrm{l}$ of extraction buffer (100 mM Tris-HCl, 400

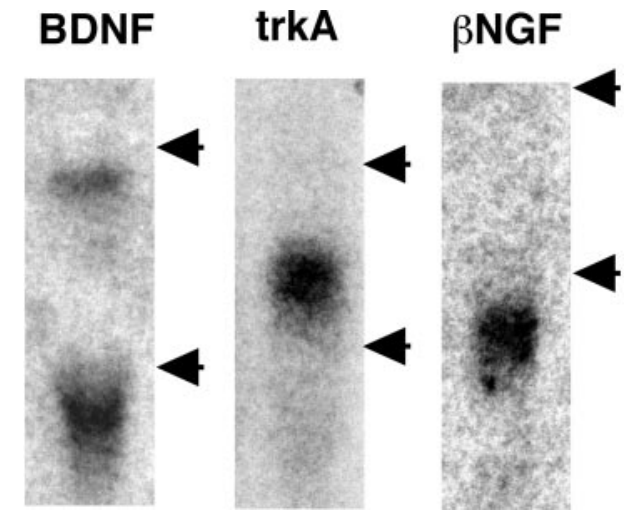

Figure 1. Northern blot analysis of oligonucleotide probes designed for the present study. The probes for BDNF and trkA were hybridized onto the total RNA obtained from naive L4 DRG, and the probe for $\beta$ NGF was hybridized onto the total RNA obtained from the sciatic nerve $14 \mathrm{~d}$ after L5 SPNL. Each probe was hybridized at the position or positions expected from the previous studies (see Materials and Methods). The top and bottom arrows indicate the positions of $28 \mathrm{~S}$ and $18 \mathrm{~S}$ rRNAs, respectively.

$\mathrm{mm} \mathrm{NaCl}, 2 \%$ bovine serum albumin, $0.05 \%$ sodium azide, $1 \mathrm{~mm}$ PMSF, $7 \mu \mathrm{g} / \mathrm{ml}$ aprotinin, and $4 \mathrm{~mm}$ EDTA). After centrifugation for $10 \mathrm{~min}$ at $4^{\circ} \mathrm{C}$ and $100,000 \times g$, the supernatant was mixed with the same volume of solution containing $0.2 \%$ Triton $\mathrm{X}-100$ and $20 \mathrm{~mm} \mathrm{CaCl}_{2}$.

Nunc-immuno-Maxisorp microtiter plates (Nunc, Roskilde, Denmark) were incubated for $2 \mathrm{hr}$ at $37^{\circ} \mathrm{C}$ with $150 \mu \mathrm{l}$ of $0.5 \mu \mathrm{g} / \mathrm{ml}$ anti-NGF monoclonal antibody in coating buffer $\left(50 \mathrm{~mm} \mathrm{Na} \mathrm{CO}_{3}-\mathrm{NaHCO}_{3}\right.$ and $0.1 \%$ sodium azide, $\mathrm{pH}$ 9.6). After removing the coating solution, nonspecific binding to the plate was blocked by incubation for $30 \mathrm{~min}$ at $37^{\circ} \mathrm{C}$ with $0.5 \%$ bovine serum albumin in coating buffer, followed by three washes with washing buffer $(50 \mathrm{~mm}$ Tris- $\mathrm{HCl}, 200 \mathrm{~mm} \mathrm{NaCl}, 10 \mathrm{~mm}$ $\mathrm{CaCl} 2,0.1 \%$ Triton $\mathrm{X}-100$, and $0.05 \%$ sodium azide, $\mathrm{pH} 7.0$ ). Each well was applied with $100 \mu \mathrm{l}$ of the supernatant described above, in triplicate, or with recombinant rat $\beta$ NGF $(15.6-500 \mathrm{pg} / \mathrm{ml}$; R \& D Systems, Minneapolis, $\mathrm{MN}$ ) and incubated at $4^{\circ} \mathrm{C}$ overnight. After three washes with washing buffer, $100 \mu \mathrm{l}$ of anti-NGF antibody $(0.4 \mathrm{U} / \mathrm{ml})$ conjugated to $\beta$-galactosidase was applied to each well and incubated for $4 \mathrm{hr}$ at $37^{\circ} \mathrm{C}$. Plates were then washed three times and then incubated with $200 \mu \mathrm{l}$ of substrate solution $(2 \mathrm{mg} / \mathrm{ml}$ chlorophenol red- $\beta$-D-galactopyranoside, 100 $\mu \mathrm{M}$ HEPES, $150 \mathrm{~mm} \mathrm{NaCl}, 2 \mathrm{~mm} \mathrm{MgCl}{ }_{2}$, and $1 \%$ bovine serum albumin) for $1 \mathrm{hr}$ at $37^{\circ} \mathrm{C}$. Absorbance was read at $570 \mathrm{~nm}$. The NGF concentration was normalized to milligrams of wet tissue. The ipsilateral-contralateral ratio of the NGF content (in picograms) per wet weight (in milligrams) of the samples was calculated and expressed as mean \pm SEM of four samples at each time point. Differences in changes of values over time were tested using one-way ANOVA. The difference between each time point and the naive control value was tested by Fisher's PLSD test. Two-tailed $p$ values $<0.05$ were considered to be significant.

Local application of anti-NGF antibody. L5 SPNL was performed as described above, except that a small piece of sponge of gelatin (Spongel; Yamanouchi, Tokyo, Japan) saturated with sheep anti-NGF antibody (100 $\mu \mathrm{g}$ in $100 \mu \mathrm{l}$ of PBS; Chemicon, Temecula, CA) or normal sheep IgG $(100 \mu \mathrm{g}$ in $100 \mu \mathrm{l}$ of PBS; Cappel, Aurora, $\mathrm{OH})$ was placed around the L4 spinal nerve near the L5 SPNL site. Thermal hyperalgesia was tested as described above, just before surgery and every day after surgery for $7 \mathrm{~d}$. BDNF mRNA expression was examined on the third and seventh days after surgery using ISH, as described above.

\section{RESULTS}

\section{Neuropathic pain behavior}

All rats that received L5 SPNL developed mechanical and heat hypersensitivity on the ipsilateral hindpaw. For example, the time course of mechanical allodynia and heat hyperalgesia obtained from 20 rats that survived for $14 \mathrm{~d}$ after L5 SPNL are shown in Figure 2. Before surgery, these rats rarely responded to the von Frey filament $(72.2 \mathrm{mN})$. From the first day after the operation, 

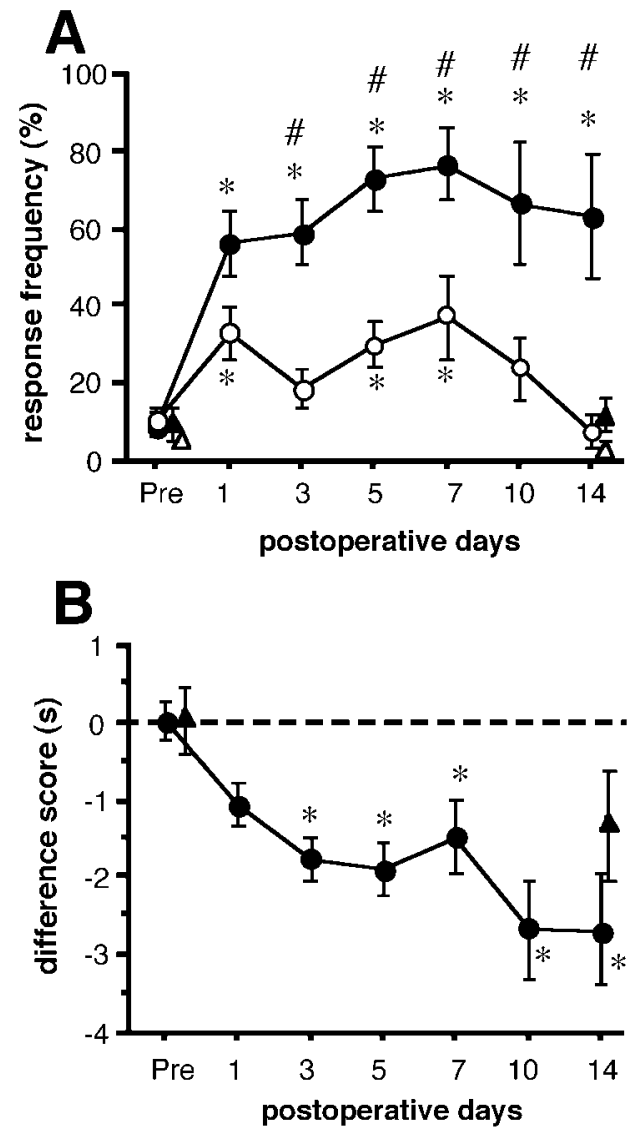

Figure 2. Time course of neuropathic pain behaviors. $A$, The response frequencies of paw withdrawals to repeated mechanical stimuli applied to the pads of the hindpaws with a von Frey filament of $72.2 \mathrm{mN}$ are expressed as a percentage (mean \pm SEM) of trials. Data from the ipsilateral (closed symbols) and contralateral (open symbols) side of 20 rats that received L5 SPNL (circles) and five sham-operated rats (triangles) are shown. There was a significant group effect between the ipsilateral and contralateral side of the L5 SPNL group $(p<0.05$, two-way repeated measures ANOVA). Number signs indicate significant differences from the contralateral side ( $p<0.05$, paired $t$ test). Asterisks indicate significant differences from the preoperative value (Pre) $(p<0.05$, one-way ANOVA followed by Fisher's PLSD). $B$ is the difference score (latency on the operated side - latency on the contralateral side) to the radiant heat stimuli obtained from the same rats with the mechanical stimuli. Data obtained from 20 rats that received L5 SPNL (closed circles) and five sham-operated rats (closed triangles) are expressed as seconds (mean \pm SEM). There was a significant change with time in the L5 SPNL group $(p<0.05$, one-way ANOVA). Asterisks indicate significant difference from the preoperative value (Pre) $(p<0.05$ by Fisher's PLSD).

these rats responded to the von Frey filament on 58\% of the trials on the ipsilateral side, and the mean response frequency was relatively constant until killing (one-way repeated measures ANOVA followed by Fisher's PLSD) (Fig. $2 A$ ). A small increase in the mean response frequency was also seen on the contralateral side, although it was significantly different from the ipsilateral side (paired $t$ test) (Fig. 2A). Application of the von Frey filament on the ipsilateral side often led to a sustained lifting, shaking, and licking of the paw, whereas the response on the contralateral side was brisk and short-lasting. There was no significant change in sham-operated rats between the preoperative day and $14 \mathrm{~d}$ after the sham operation (paired $t$ test) (Fig. $2 A$ ).

Before surgery, the radiant heat stimulus produced pawwithdrawal at a $9.4 \pm 0.4 \mathrm{sec}$ latency on both sides; where the difference score was virtually zero $(0.03 \pm 0.2 \mathrm{sec})$. After L5 SPNL, the difference score became a minus value, and one-way repeated measures ANOVA showed a significant time course change. The mean difference scores at 3, 5, 10, and $14 \mathrm{~d}$ after L5 SPNL were significantly lower than the preoperative value (Fisher's PLSD) (Fig. 2B). The mean difference score from five shamoperated rats slightly decreased at $14 \mathrm{~d}$ after surgery, but it did not reach significance compared with the preoperative value ( $p=$ 0.07 by paired $t$ test).

\section{BDNF expression increased in the ipsilateral L4 DRG after L5 spinal nerve ligation}

In control rats, $7.8 \pm 2.5 \%$ of L4 DRG neurons were positively $(2 \leq \mathrm{S} / \mathrm{N}$ ratio) labeled for BDNF mRNA. However, the grain density of almost all of them was relatively low $(\mathrm{S} / \mathrm{N}$ ratio $<4)$. After L5 SPNL, some neurons intensely labeled for BDNF mRNA were observed in the ipsilateral L4 DRG, whereas the labeling in the contralateral side remained weak. For example, dark-field photomicrographs of the L4 DRG at $14 \mathrm{~d}$ after injury are presented in Figure 3, $A$ and $B$.

To quantify the increase in BDNF mRNA expression in detail, we measured the signal intensity of each neuron (at least 250 neurons) in a randomly selected L4 DRG section from each rat. Cross-sectional area $\mathrm{S} / \mathrm{N}$ ratio distributions of L4 DRG neurons from a typical rat, $14 \mathrm{~d}$ after L5 SPNL, are shown in Figure 3, C and $D$. The increase in signal intensity was seen mainly in smallsized $\left(<600 \mu \mathrm{m}^{2}\right)$ and medium-sized $\left(600-1200 \mu \mathrm{m}^{2}\right)$ neurons, but a small population of large-sized $\left(>1200 \mu \mathrm{m}^{2}\right)$ neurons also increased signal intensity.

The time course of BDNF mRNA expression in the L4 DRG is presented in Figure $3 E$. Although there was no difference on the first day, a significant increase in BDNF mRNA expression in the ipsilateral L4 DRG was first observed on the third day after L5 SPNL, and the increase was still significant on the 28th day after injury compared with the contralateral side (paired $t$ test) (Fig. 3E).

The increase in BDNF expression was confirmed at the protein level by immunohistochemistry $14 \mathrm{~d}$ after L5 SPNL (Fig. 3F, $G$ ). Thus, the proportion of BDNF immunoreactive neurons in the ipsilateral L4 DRG was significantly greater than that in the contralateral side (paired $t$ test) (Table 1 ), and the percentages of BDNF-immunoreactive neurons are consistent with the percentages of BDNF mRNA-expressing neurons on both sides (Table 1). In addition, the intensity of BDNF-immunoreactivity in some neurons markedly increased in the ipsilateral L4 DRG compared with the contralateral side (Fig. 3, arrows). Consistent with the ISHH data (Fig. 3C,D), most of these BDNF-immunoreactive neurons were small or medium in size.

\section{Intrathecal injection of anti-BDNF antibody attenuates thermal hyperalgesia}

To test the contribution of endogenous BDNF to pain behavior in this model, we neutralized BDNF in the superficial dorsal horn of the spinal cord by intrathecal injection of anti-BDNF antibody $3 \mathrm{~d}$ after L5 SPNL, when all rats developed thermal hyperalgesia (Fig. 4, asterisk), as demonstrated by significant shifts of difference scores of both groups to minus values. Anti-BDNF antibody injection significantly reduced the shift for at least $150 \mathrm{~min}$ compared with the preinjection value (Fig. 4, number sign), although this effect disappeared as early as $4 \mathrm{hr}$ after injection. Normal sheep IgG injection had no significant effect on the shift of difference score for the duration of the testing period. 

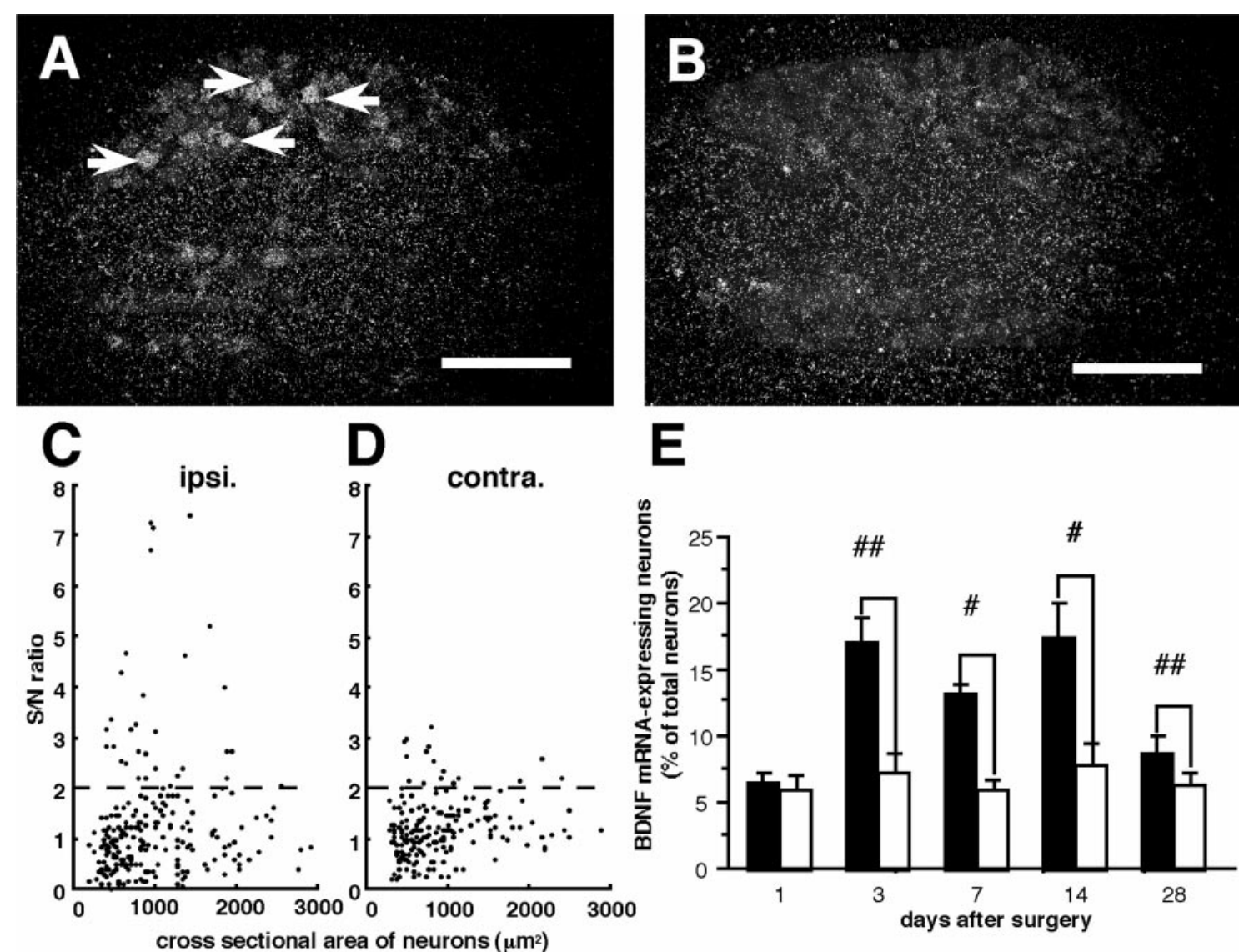

$\mathbf{E}$
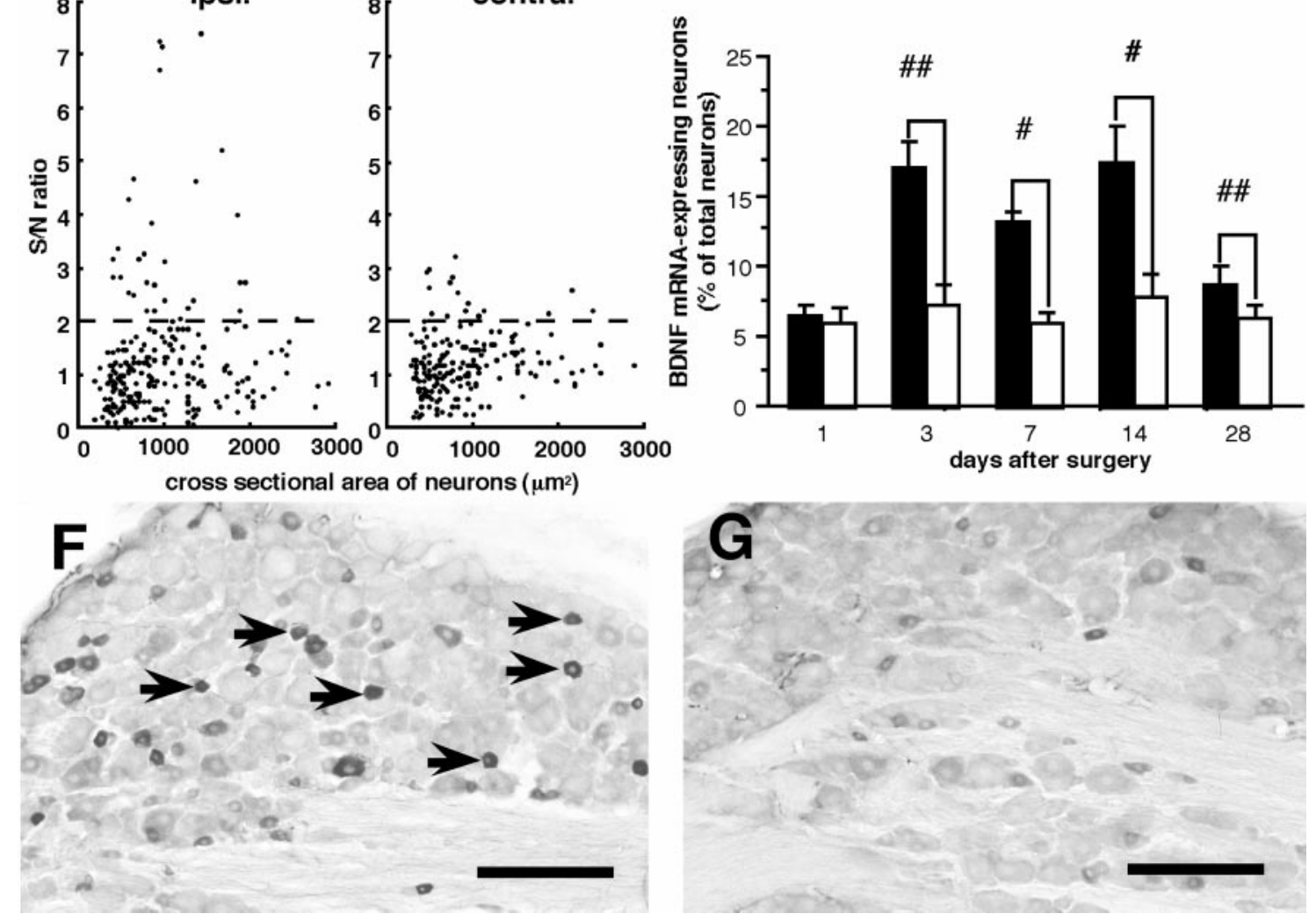

Figure 3. Effect of L5 spinal nerve ligation on BDNF protein and mRNA expression in L4 DRG neurons. $A$ and $B$ are dark-field photomicrographs showing in situ hybridization products for BDNF mRNA $14 \mathrm{~d}$ after surgery. In the ipsilateral L4 DRG $(A)$, several neurons were intensely labeled (arrows) compared with the contralateral L4 DRG $(B)$. Scale bars, $300 \mu \mathrm{m}$. $C$ and $D$ are scatterplot diagrams of BDNF mRNA expression in the ipsilateral $(C$, ipsi.) and contralateral (D, contra.) L4 DRG from one representative rat. Individual cell profiles are plotted according to the cross-sectional area (in square micrometers; along the $x$-axis) and $\mathrm{S} / \mathrm{N}$ ratio (along the $y$-axis). The dashed lines indicate the borderline between the negatively and positively labeled neurons $(\mathrm{S} / \mathrm{N}$ ratio $=2)$. A subpopulation of small $\left(<600 \mu \mathrm{m}^{2}\right)$ - and medium $\left(600-1200 \mu \mathrm{m}^{2}\right)$-sized neurons showed an increase in $\mathrm{S} / \mathrm{N}$ ratio on the ipsilateral side compared with the contralateral side. $E$ is a bar graph showing means \pm SEM (\%) of BDNF mRNA-expressing neurons in the L4 DRG at various times after L5 spinal nerve ligation ( $n=4$ at each time point). Filled bars and open bars represent the values on the ipsilateral and contralateral sides, respectively. $\# p<0.05$; \#\#p $<0.01$ by paired $t$ test. $F$ and $G$ are photomicrographs of BDNF immunohistochemistry $14 \mathrm{~d}$ after surgery. On the ipsilateral side $(F)$, the immunoreactive intensity of some small-sized neurons markedly increased compared with the contralateral side $(G)$. Scale bars, $200 \mu \mathrm{m}$.

\section{Coexpression of trkA mRNA with BDNF mRNA in the L4 DRG}

To address the contribution of NGF to the upregulation of BDNF expression in the ipsilateral L4 DRG, we first examined the coexpression of trkA, the high-affinity NGF receptor, mRNA and BDNF mRNA using ISHH on the 6 - $\mu$ m-thick serial sections of L4 DRG obtained $14 \mathrm{~d}$ after L5 SPNL (Fig. 5, Table 2). Neurons with an $\mathrm{S} / \mathrm{N}$ ratio of $\geq 2$ were taken as positive neurons for both
Table 1. The percentage of L4 DRG neurons expressing BDNF immunoreactivity (IR) and mRNA $14 \mathrm{~d}$ after L5 spinal nerve ligation

\begin{tabular}{lcc} 
& IR & mRNA \\
\hline Ipsilateral & $23.8 \pm 1.4 \%^{*}$ & $17.5 \pm 2.7 \%^{*}$ \\
Contralateral & $8.1 \pm 1.6 \%$ & $9.1 \pm 2.6 \%$
\end{tabular}

$* p<0.05$ versus contralateral side by paired $t$ test $(n=4)$. 


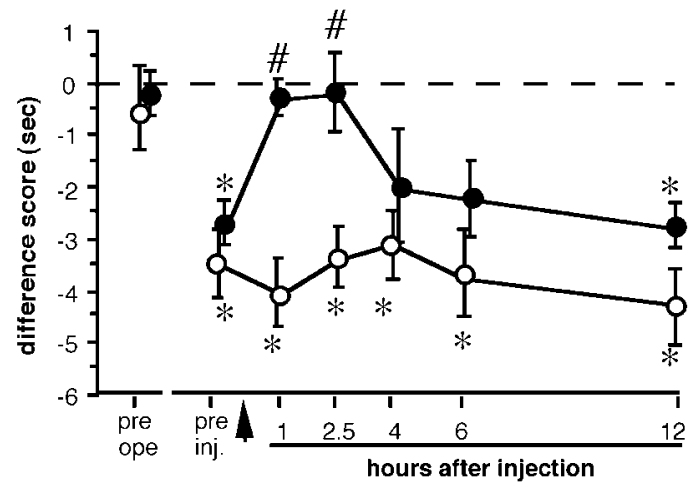

Figure 4. Effects of intrathecal injection (arrow) of anti-BDNF antibody (20 $\mu \mathrm{g}$, closed circles) or normal sheep IgG (20 $\mu \mathrm{g}$, open circles) on paw withdrawal response to noxious heat of the rats that received L5 SPNL. Difference scores were calculated by subtracting contralateral withdrawal latencies from ipsilateral withdrawal latencies and expressed as mean \pm SEM ( $n=8$ for each treatment). Thermal hyperalgesia was abolished for at least $2.5 \mathrm{hr}$ by anti-BDNF antibody injection, whereas normal sheep IgG injection had no significant effect on the behavior. ${ }^{*} p<0.05$ versus before L5 SPNL ( pre ope); \#p $<0.05$ versus before injection ( pre inj.) by one-way ANOVA followed by Fisher's PLSD.

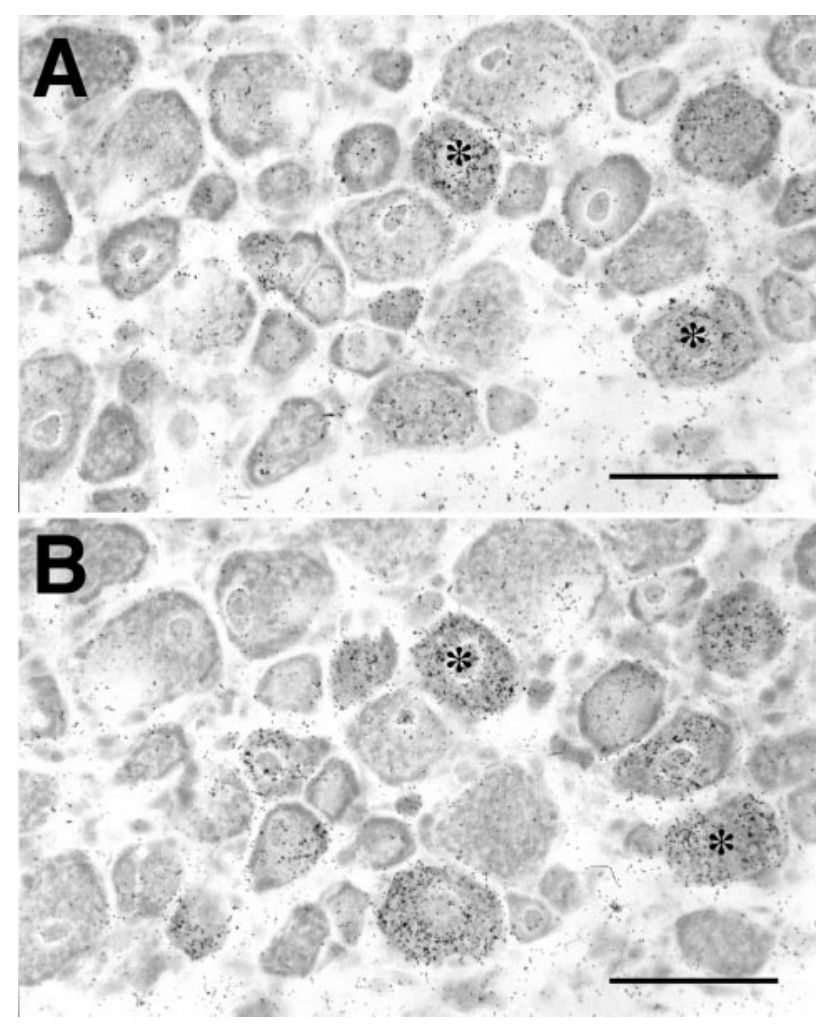

Figure 5. Coexpression of BDNF mRNA with trkA mRNA in the ipsilateral L4 DRG $14 \mathrm{~d}$ after L5 spinal nerve ligation. A pair of serial sections processed for in situ hybridization for BDNF mRNA $(A)$ and trkA mRNA $(B)$. Asterisks indicate the neurons that coexpress both mRNAs. Scale bars, $100 \mu \mathrm{m}$.

mRNAs. In this experiment, $33.7 \pm 0.9$ and $32.1 \pm 1.7 \%$ of neurons expressed trkA mRNA in the ipsilateral and contralateral L4 DRG, respectively, and there was no significant difference between these two values (paired $t$ test). The proportion of BDNF mRNA-expressing neurons in the trkA mRNA-expressing neurons was significantly higher in the ipsilateral L4 DRG com-
Table 2. Coexpression of tkA mRNA with BDNF mRNA in L4 DRG $14 \mathrm{~d}$ after $\mathrm{L} 5$ spinal nerve ligation

\begin{tabular}{lll} 
& BDNF/trkA & trkA/BDNF \\
\hline Ipsilateral & $28.1 \pm 3.8 \%^{*}$ & $90.3 \pm 3.3 \%$ \\
Contralateral & $12.1 \pm 1.0 \%$ & $92.9 \pm 7.1 \%$
\end{tabular}

$\mathrm{X} / \mathrm{Y}$ means the percentage of $\mathrm{X}$ mRNA-expressing cells in $\mathrm{Y}$ mRNA-expressing cells.

${ }^{*} p<0.05$ versus contralateral side by paired $t$ test $(n=4)$.

pared with the contralateral side (Table 2). Conversely, most of the BDNF mRNA-expressing neurons had trkA mRNA on both sides.

\section{NGF content increased in the ipsilateral L4 DRG after L5 spinal nerve ligation}

Next, we quantified the NGF content using ELISA. In naive control rats, the NGF concentrations in the L4 DRG, L4 spinal nerve, and sciatic nerve were $4.3 \pm 0.2,3.0 \pm 0.3$, and $2.3 \pm 0.2$ $\mathrm{pg} / \mathrm{mg}$ of wet tissue, respectively. The concentration in the sciatic nerve is similar with the value obtained in a previous report (Heumann et al., 1987). However, the concentration in the DRG was lower than the value of another report (Herzberg et al., 1997). This may reflect the difference in the use of the ELISA system or standard NGF. Therefore, we normalized the values on the ipsilateral side to contralateral values, as described in Materials and Methods. Each of the ipsilateral-contralateral NGF concentration ratios in the three tissues in naive control rats was $\sim 100 \%$. The ratio in the L4 DRG linearly increased and reached significance $14 \mathrm{~d}$ after L5 SPNL $(174.5 \pm 21.3 \%)$ (Fig. $6 A)$. The ratio in the L4 spinal nerve did not show any statistical change throughout the period (Fig. $6 B$ ). The ratio in the sciatic nerve significantly increased 1 and $4 \mathrm{~d}$ after L5 SPNL (304.3 \pm 29.5 and $156.5 \pm 2.5 \%$ ), but returned to around normal the level at 7 and $14 \mathrm{~d}$ after injury (Fig. 6C).

In sham-operated rats, there was no difference of NGF concentration between the ipsilateral and contralateral L4 DRG, the L4 spinal nerves, and the sciatic nerves $14 \mathrm{~d}$ after surgery (the ipsilateral-contralateral NGF concentration ratios were $93.1 \pm$ 1.5, $93.5 \pm 8.6$, and $94.0 \pm 6.3 \%$, respectively) (Fig. 6).

\section{NGF mRNA increased in the ipsilateral sciatic nerve but not in the L4 DRG}

To address the question of where the NGF is synthesized, Northern blot analysis and ISHH for NGF mRNA were performed in the L4 and L5 DRG, the L4 spinal nerve, and the sciatic nerve. In the contralateral tissue, NGF mRNA expression was just above the detectable level. L5 SPNL induced clear upregulation of NGF mRNA in the ipsilateral L5 DRG and sciatic nerve, but in neither the ipsilateral L4 DRG nor L4 spinal nerve at $14 \mathrm{~d}$ after injury (Fig. $7 A, B$ ). To rule out the possibility that the expression of NGF mRNA occurs in a very small proportion of DRG neurons or other cells, ISHH was performed. NGF mRNA expression could not be detected in the ipsilateral L4 DRG at $14 \mathrm{~d}$ after injury (Fig. 7C).

\section{Local application of anti-NGF antibody prevented the development of thermal hyperalgesia after L5 SPNL}

NGF is a neurotrophic factor that is retrogradely transported to the DRG from the periphery. Because we found that the synthesis of NGF increased in the ipsilateral sciatic nerve in this neuropathic pain model, an increased amount of NGF may be transported to the ipsilateral L4 DRG. Therefore, we aimed to block 


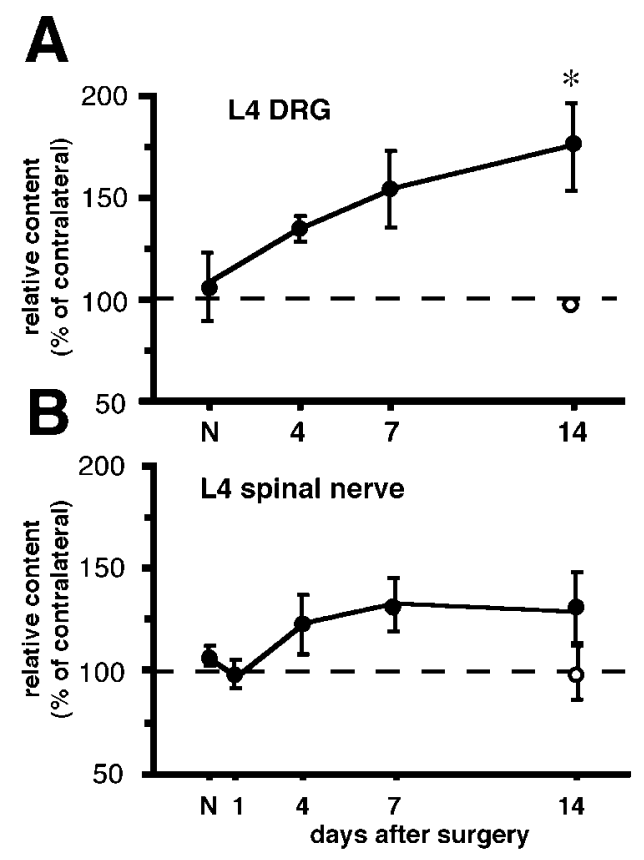

C

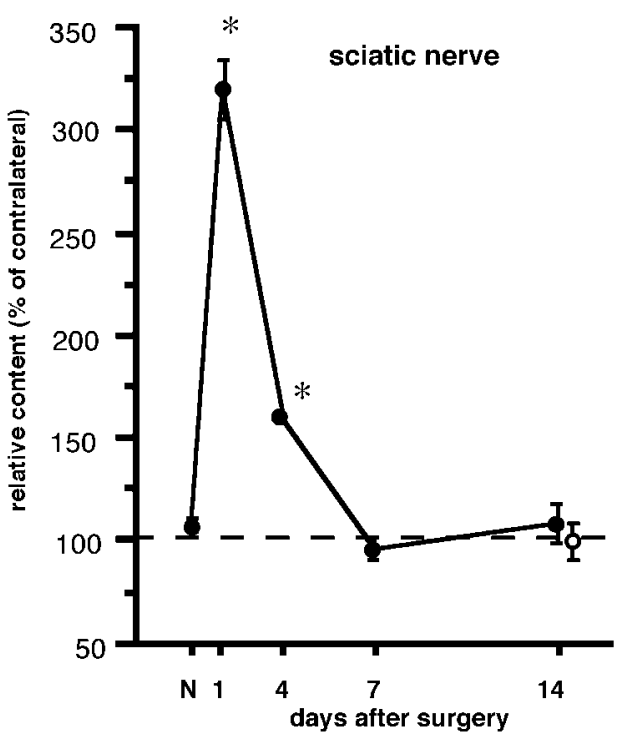

Figure 6. Change in NGF content in the L4 DRG, L4 SpN and ScN after L5 spinal nerve ligation (closed circles) and after sham operation (open circles). NGF content was measured by ELISA, and the values of the ipsilateral side are presented as mean \pm SEM (\%) of the contralateral side $(n=4$ independent experiments). ${ }^{*} p<0.05$ versus naive control $(N)$ by one-way ANOVA followed by Fisher's PLSD. the NGF being transported in the L4 spinal nerve using local application of anti-NGF antibody on the surface of the nerve (Fig. 8).

The time course of the development of thermal hyperalgesia was significantly different between the anti-NGF antibody and the normal sheep IgG-treated groups (two-way repeated measures ANOVA). Significant thermal hyperalgesia was apparent as early as the first days after surgery and lasted at least $7 \mathrm{~d}$ in the normal sheep IgG-injected group. As was expected, the anti-NGF antibody-injected group did not show the significant shift of difference score to a minus value until the sixth day after L5 SPNL. However, anti-NGF antibody application to the L4 spinal nerve did not prevent the increase in BDNF expression in the ipsilateral L4 DRG at the third or seventh days after surgery (Table 3).

\section{DISCUSSION}

In this study, we demonstrated the following new findings: (1) L5 SPNL induced a significant increase in the expression of BDNF in a subpopulation of neurons in the ipsilateral L4 DRG. The increase was significant from the third day and continued for at least 4 weeks after surgery. (2) Intrathecal injection of antiBDNF antibody attenuated thermal hyperalgesia for a few hours. (3) Most of the BDNF mRNA-expressing neurons in the ipsilateral L4 DRG coexpressed trkA mRNA. The percentage of BDNF mRNA-expressing cells of the trkA mRNA-expressing cells was significantly higher in the ipsilateral L4 DRG than the contralateral side. (4) NGF content linearly increased in the ipsilateral L4 DRG after L5 SPNL, with this increase reaching statistical significance at the 14th day after surgery. (5) NGF mRNA increased in the ipsilateral sciatic nerve and L5 DRG, but not in the ipsilateral L4 DRG, at 14 d after surgery. (6) The local application of anti-NGF antibody to the L4 spinal nerve prevented the development of thermal hyperalgesia for $5 \mathrm{~d}$ after SPNL, but did not block the increase in BDNF expression in the ipsilateral L4 DRG.

The percentage of BDNF mRNA-expressing neurons in the lumbar DRG has been found to vary from 11 to $38 \%$ in previous reports (Cho et al., 1997; Michael et al., 1997; Kashiba and Senba, 1999; Mannion et al., 1999). This variation is likely the result of differences in probe design and the criteria used to distinguish between positive and negative neurons. In the current study, we observed that $7.8 \pm 2.5 \%$ of naive L4 DRG neurons expressed BDNF mRNA. This value may underestimate the exact value; however, our data are very consistent with the values obtained using immunohistochemistry (Table 1).

BDNF is constitutionally expressed in DRG neurons, especially in small- and medium-sized neurons (Zhou and Rush, 1996), and increases after direct nerve injury (Cho et al., 1998; Kashiba and Senba, 1999). Therefore, in the present study the increase in BDNF expression in a subpopulation of ipsilateral L4 DRG neurons can be explained by direct injury to these neurons. However, such neurons must be relatively rare, because a clear increase in BDNF immunoreactivity was observed mainly in small-sized neurons in the ipsilateral L4 DRG in this study (Fig. $3 F$ ), whereas axotomy increases BDNF immunoreactivity and BDNF mRNA expression in mainly medium- and large-sized neurons (Cho et al., 1998; Kashiba and Senba, 1999).

BDNF has recently been recognized as a sensory neuromodulator in the spinal dorsal horn (Kafitz et al., 1999; Kerr et al., 1999; Mannion et al., 1999; Thompson et al., 1999). BDNF that is synthesized in the DRG is transported to the central terminals of the primary afferents in the spinal dorsal horn (Zhou and Rush, 1996; Michael et al., 1997), is released, and acts on the trkB receptor on the second-order sensory neurons. As reported in hippocampus (Suen et al., 1997), BDNF can cause phosphorylation of the NMDA receptor on spinal neurons, and this is known as one of the mechanisms of central sensitization. In fact, spinal neurons show greater response to nociceptive input after exogenous BDNF treatment (Kerr et al., 1999; Thompson et al., 1999). The contribution of endogenous BDNF to mechanical allodynia after L5 SPNL has been reported by direct infusion of antiBDNF antibody to the injured L5 DRG (Zhou et al., 2000). Systemic administration of anti-BDNF antibody relieves mechanical and thermal hyperalgesia in rats that received partial tran- 


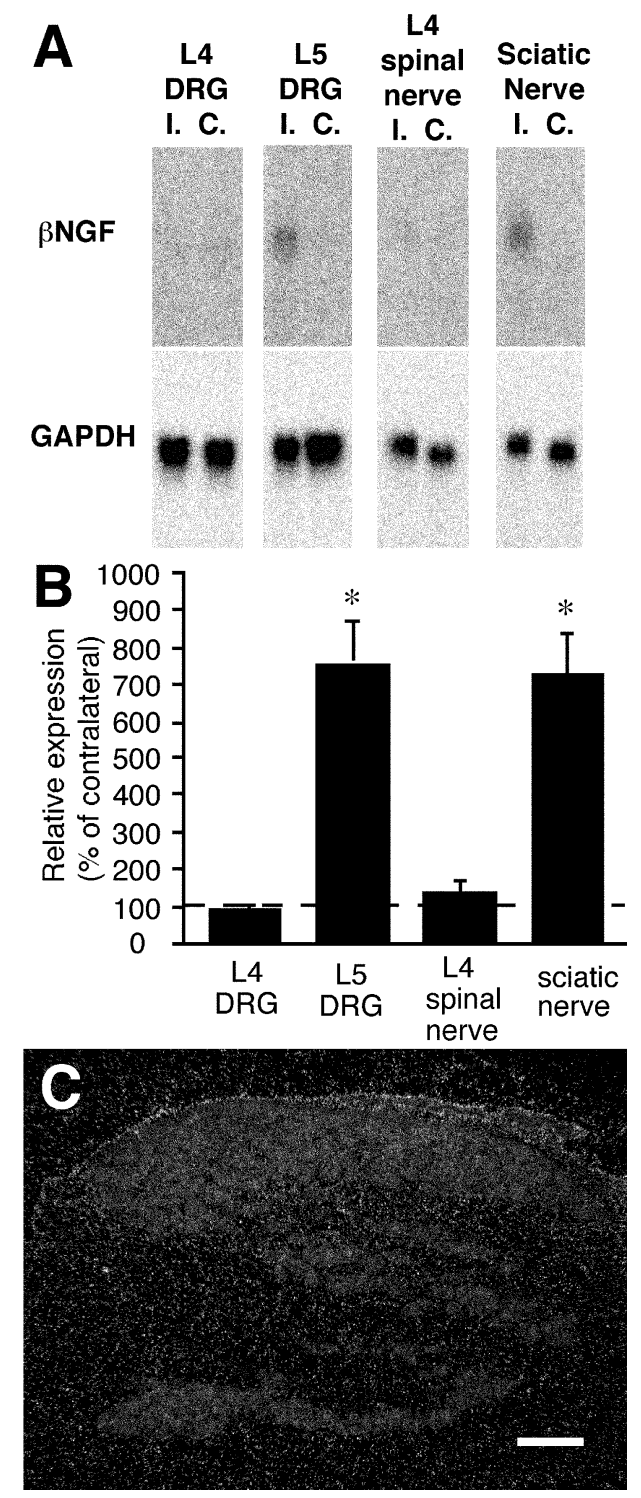

Figure 7. Expression of NGF mRNA in the L4 and L5 DRG, L4 spinal nerve, and sciatic nerve $14 \mathrm{~d}$ after L5 spinal nerve ligation. Northern blot analysis $(A)$ revealed clear upregulation of NGF mRNA in the ipsilateral $(I$.$) L5 DRG and sciatic nerve compared with the contralateral side (C$.). The NGF mRNA expression in the L4 DRG and L4 spinal nerve was just above the detectable level, and there was no difference between the ipsilateral and contralateral sides. $B$ is a bar graph of relative expression of NGF mRNA obtained from four pooled samples. Relative expression is defined as the expression on the ipsilateral side relative to the mean \pm SEM $(\%)$ of the contralateral side. The difference from $100 \%$ was tested by $t$ test. ${ }^{*} p<0.05$. In situ hybridization was performed to rule out the possibility that a very small number of cells expressed NGF mRNA in the ipsilateral L4 DRG $(C)$. There was no accumulation of silver grains on any specific cells in the DRG. Scale bar, $300 \mu \mathrm{m}$.

section of the sciatic nerve (Theodosiou et al., 1999). In addition to its function in the dorsal horn, BDNF, which increased in the ipsilateral L4 DRG, may act in the periphery or in a paracrine manner, because some DRG neurons express trkB, a high-affinity BDNF receptor (McMahon et al., 1994; Kashiba et al., 1995, 1997; Wright and Snider, 1995). For example, BDNF injection into the rat hindpaw induces thermal hyperalgesia (Shu et al., 1999), and exogenous BDNF directly delivered to the intact DRG causes mechanical allodynia (Zhou et al., 2000). In any case, we

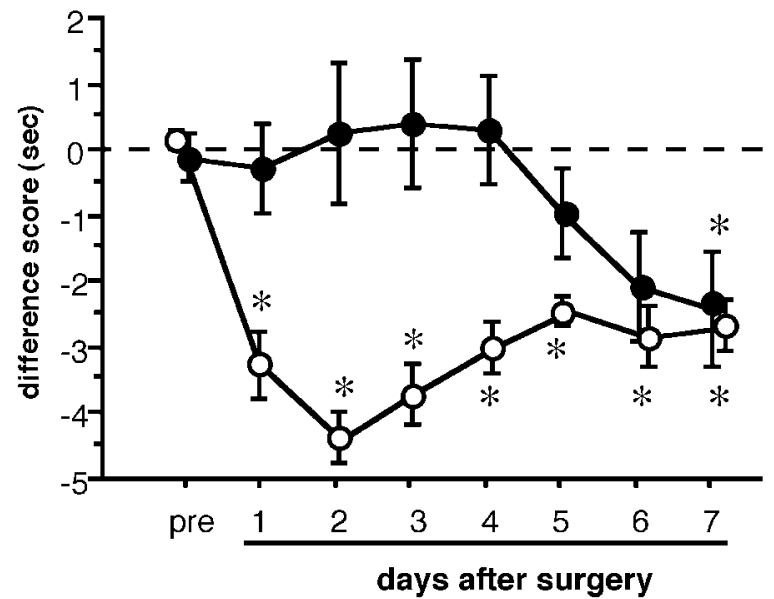

Figure 8. The effect of local application of anti-NGF antibody on thermal hyperalgesia in the L5 spinal nerve ligation (L5 SPNL) model. A small piece of gelatin sponge saturated with sheep anti-NGF antibody $(100 \mu \mathrm{g}$, filled circles, $n=5-9)$ or normal sheep $\operatorname{IgG}(100 \mu \mathrm{g}$, open circles, $n=5)$ was placed on the surface of the L4 spinal nerve when the L5 SPNL was performed. The anti-NGF antibody prevented the development of thermal hyperalgesia for up to $6 \mathrm{~d}$ after surgery. Data are expressed as mean \pm SEM. ${ }^{*} p<0.05$ versus before L5 SPNL ( pre) by one-way ANOVA followed by Fisher's PLSD.

Table 3. Local application of anti-NGF antibody failed to prevent the increase in BDNF mRNA expression in the ipsilateral L4 DRG after L5 spinal nerve ligation

\begin{tabular}{lll} 
& \multicolumn{2}{l}{ Ipsilateral L4 DRG } \\
\cline { 2 - 3 } & Anti-NGF & $\begin{array}{l}\text { Normal } \\
\text { sheep IgG }\end{array}$ \\
\hline 3 POD & $14.6 \pm 2.5 \%$ & $14.7 \pm 2.1 \%$ \\
7 POD & $10.6 \pm 1.2 \%$ & $12.2 \pm 1.2 \%$
\end{tabular}

There was no significance between the anti-NGF group and normal sheep IgG group. Mean \pm SE; $n=4$.

POD, Postoperative days.

demonstrated that endogenous BDNF contributed to thermal hyperalgesia at the spinal dorsal horn level using intrathecal injection of anti-BDNF antibody. The BDNF that increased in intact primary afferent neurons in the spared L4 DRG thus has a role in the exaggerated evoked responses observed in this neuropathic pain model.

The contribution of NGF to the phenotypic change of DRG neurons has been investigated in some experimental inflammation models. NGF increases substance P, CGRP, and BDNF expression in lumbar DRG neurons after intraplantar injection of complete Freund's adjuvant to the hindpaw (Donnerer et al., 1992; Cho et al., 1997). In previous studies (Fukuoka et al., 1998a,b) and the present study, we demonstrated that these three molecules increased in the spared L4 DRG after L5 SPNL. In this respect, the phenotypic change of the spared L4 DRG in this neuropathic pain model is just like that of the peripheral inflammation model. Therefore, we anticipated that NGF might contribute to the upregulation of these molecules in this model and investigated coexpression of BDNF mRNA with trkA mRNA in the L4 DRG in this model. As was reported previously (Kashiba et al., 1997), most of the BDNF mRNA-expressing neurons also expressed trkA mRNA in the L4 DRG on both sides (Table 2). The percentage of BDNF mRNA-expressing cells of trkA cells 
significantly increased in the ipsilateral L4 DRG compared with that in the contralateral DRG (Table 2). The percentage on the contralateral side is also quite consistent with a previous report (Cho et al., 1997). These data suggest that the increase in BDNF expression occurs mainly in trkA cells.

Recently, Shen et al. (1999) reported that NGF mRNA increased in the directly injured DRG after spinal nerve injury. In the present study, we confirmed their data using Northern blot analysis. On the other hand, there was no increase in NGF mRNA in the ipsilateral L4 DRG at $14 \mathrm{~d}$ after injury (Fig. 7), when NGF content was significantly elevated in this area (Fig. $6 A$ ). The lack of an increase in the mRNA is understandable, given that the L4 spinal nerve was not injured, only the L5 spinal nerve. This raises the question of why NGF content increased in the ipsilateral L4 DRG. Most probable explanation for these data are that NGF is synthesized elsewhere and transported to the L4 DRG. A possible source of NGF is the directly injured L5 DRG, in which NGF mRNA increased $14 \mathrm{~d}$ after L5 SPNL (Fig. 7A, $B$ ). However, there is no direct anatomical connection between the L4 and L5 DRG through which the synthesized NGF can be transported. We found that NGF content transiently increased at 1 and $4 \mathrm{~d}$ after injury and then returned to normal (Fig. 6C), whereas NGF mRNA is still clearly upregulated at $14 \mathrm{~d}$ after injury in the ipsilateral sciatic nerve (Fig. $7 A, B$ ). These data suggest that NGF may be synthesized in the sciatic nerve, perhaps in the L5 spinal nerve distal to the ligation site, diffused into the L4 spinal nerve that retrogradely transports NGF to the L4 DRG neurons. However, we do not have direct evidence that NGF synthesized in the sciatic nerve, perhaps in the L5 spinal nerve distal to the ligation site, diff uses into the spared L4 spinal nerve. There are also some problems in this explanation: BDNF expression significantly increases (as early as $3 \mathrm{~d}$ after L5 SPNL) (Fig. $3 E$ ) in the L4 DRG, before NGF content in the tissue significantly elevates (14 d) (Fig. 6 $A$ ). Local application of anti-NGF antibody to the L4 spinal nerve prevented the development of thermal hyperalgesia (Fig. 8), but did not block the increase in BDNF expression in the L4 DRG in the present study (Table 3). Therefore, NGF that was synthesized in the ipsilateral sciatic nerve, and BDNF that increased in the spared L4 DRG may independently contribute to thermal hyperalgesia in this model. In any case, the relationship between these two neurotrophins seems not to be as simple as that in inflammatory pain states.

In conclusion, we demonstrated the increase in BDNF expression in the spared L4 DRG neurons after L5 SPNL and suggest that this phenotypical change likely contributes to thermal hyperalgesia in this model. NGF that was synthesized in the injured nerve also contributes to thermal hyperalgesia. The dynamic changes in NGF content and BDNF expression in the uninjured DRG might be important pathomechanisms of this neuropathic pain model.

\section{REFERENCES}

Amara SG, Arriza JL, Leff SE, Swanson LW, Evans RM, Rosenfeld MG (1985) Expression in brain of a messenger RNA encoding a novel neuropeptide homologous to calcitonin gene-related peptide. Science 229:1094-1097.

Apfel SC, Wright DE, Wiideman AM, Dormia C, Snider WD, Kessler JA (1996) Nerve growth factor regulates the expression of brain-derived neurotrophic factor mRNA in the peripheral nervous system. Mol Cell Neurosci 7:134-142.

Bennett GJ, Xie Y (1988) A peripheral mononeuropathy in rat that produces disorders of pain sensation like those seen in man. Pain 33:87-107.

Cho HJ, Kim SY, Park MJ, Kim DS, Kim JK, Chu MY (1997) Expression of mRNA for brain-derived neurotrophic factor in the dorsal root ganglion following peripheral inflammation. Brain Res 749:358-362.
Cho HJ, Kim JK, Park HC, Kim JK, Kim DS, Ha SO, Hong HS (1998) Changes in brain-derived neurotrophic factor immunoreactivity in rat dorsal root ganglia, spinal cord, and gracile nuclei following cut or crush injuries. Exp Neurol 154:224-230.

Donnerer J, Schuligoi R, Stein C (1992) Increased content and transport of substance $\mathrm{P}$ and calcitonin gene-related peptide in sensory nerves innervating inflamed tissue: evidence for a regulatory function of nerve growth factor in vivo. Neuroscience 49:693-698.

Ernfors P, Rosario CM, Merlio JP, Grant G, Aldskogius H, Persson H (1993) Expression of mRNAs for neurotrophin receptors in the dorsal root ganglion and spinal cord during development and following peripheral or central axotomy. Brain Res Mol Brain Res 17:217-226.

Fukuoka T, Tokunaga A, Kondo E, Miki K, Tachibana T, Noguchi K (1998a) Change in mRNAs for neuropeptides and the GABA(A) receptor in dorsal root ganglion neurons in a rat experimental neuropathic pain model. Pain 78:13-26.

Fukuoka T, Miki K, Tokunaga A, Kondo E, Noguchi K (1998b) Upregulation of calcitonin gene-related peptide and preproyachykinin mRNA in L4 dorsal root ganglion neurons following L5 spinal nerve ligation; a rat neuropathic pain model. Soc Neurosci Abstr 24:1392.

Fukuoka T, Tokunaga A, Kondo E, Noguchi K (2000) The role of neighboring intact dorsal root ganglion neurons in a rat neuropathic pain model. In: Progress in pain research and management, Vol 16 (Devor M, Rowbotham MC, Wiesenfeld-Hallin Z, eds), pp 137-146. Seattle: IASP.

Herzberg U, Eliav E, Dorsey JM, Gracely RH, Kopin IJ (1997) NGF involvement in pain induced by chronic constriction injury of the rat sciatic nerve. NeuroReport 8:1613-1618.

Heumann R, Korsching S, Bandtlow C, Thoenen H (1987) Changes of nerve growth factor synthesis in nonneuronal cells in response to sciatic nerve transection. J Cell Biol 104:1623-1631.

Kafitz KW, Rose CR, Thoenen H, Konnerth A (1999) Neurotrophinevoked rapid excitation through TrkB receptors. Nature 401:918-921.

Kashiba H, Senba E (1999) Up- and down-regulation of BDNF mRNA in distinct subgroups of rat sensory neurons after axotomy. NeuroReport 10:3561-3565.

Kashiba H, Noguchi K, Ueda Y, Senba E (1995) Coexpression of trk family members and low-affinity neurotrophin receptors in rat dorsal root ganglion neurons. Brain Res Mol Brain Res 30:158-164.

Kashiba H, Ueda Y, Ueyama T, Nemoto K, Senba E (1997) Relationship between BDNF- and trk-expressing neurones in rat dorsal root ganglion: an analysis by in situ hybridization. NeuroReport 8 : 1229-1234.

Kerr BJ, Bradbury EJ, Bennett DL, Trivedi PM, Dassan P, French J, Shelton DB, McMahon SB, Thompson SW (1999) Brain-derived neurotrophic factor modulates nociceptive sensory inputs and NMDAevoked responses in the rat spinal cord. J Neurosci 19:5138-5148.

Kim SH, Chung JM (1992) An experimental model for peripheral neuropathy produced by segmental spinal nerve ligation in the rat. Pain 50:355-363.

Li Y, Dorsi MJ, Meyer RA, Belzberg AJ (2000) Mechanical hyperalgesia after an L5 spinal nerve lesion in the rat is not dependent on input from injured nerve fibers. Pain 85:493-502.

Ma W, Bisby MA (1998) Increase of preprotachykinin mRNA and substance P immunoreactivity in spared dorsal root ganglion neurons following partial sciatic nerve injury. Eur J Neurosci 10:2388-2399.

Maisonpierre PC, Le BM, Espinosa III R, Ip NY, Belluscio L, de la Monte SM, Squinto S, Furth ME, Yancopoulos GD (1991) Human and rat brain-derived neurotrophic factor and neurotrophin-3: gene structures, distributions, and chromosomal localizations. Genomics 10:558-568.

Mannion RJ, Costigan M, Decosterd I, Amaya F, Ma QP, Holstege JC, Ji RR, Acheson A, Lindsay RM, Wilkinson GA, Woolf CJ (1999) Neurotrophins: peripherally and centrally acting modulators of tactile stimulus-induced inflammatory pain hypersensitivity. Proc Natl Acad Sci USA 96:9385-9390.

McMahon SB, Armanini MP, Ling LH, Phillips HS (1994) Expression and coexpression of Trk receptors in subpopulations of adult primary sensory neurons projecting to identified peripheral targets. Neuron 12:1161-1171.

Meakin SO, Suter U, Drinkwater CC, Welcher AA, Shooter EM (1992) The rat trk protooncogene product exhibits properties characteristic of the slow nerve growth factor receptor. Proc Natl Acad Sci USA 89:2374-2378

Michael GJ, Averill S, Nitkunan A, Rattray M, Bennett DL, Yan Q, Priestley JV (1997) Nerve growth factor treatment increases brainderived neurotrophic factor selectively in TrkA-expressing dorsal root ganglion cells and in their central terminations within the spinal cord. J Neurosci 17:8476-8490.

Schwartz JP (1988) Stimulation of nerve growth factor mRNA content in C6 glioma cells by a $\beta$-adrenergic receptor and by cyclic AMP. Glia 1:282-285.

Seltzer Z, Dubner R, Shir Y (1990) A novel behavioral model of neuropathic pain disorders produced in rats by partial sciatic nerve injury. Pain 43:205-218. 
Shen H, Chung JM, Chung K (1999) Expression of neurotrophin mRNAs in the dorsal root ganglion after spinal nerve injury. Brain Res Mol Brain Res 64:186-192.

Shu XQ, Llinas A, Mendell LM (1999) Effects of trkB and trkC neurotrophin receptor agonists on thermal nociception: a behavioral and electrophysiological study. Pain 80:463-470.

Suen PC, Wu K, Levine ES, Mount HT, Xu JL, Lin SY, Black IB (1997) Brain-derived neurotrophic factor rapidly enhances phosphorylation of the postsynaptic $N$-methyl-D-aspartate receptor subunit 1 . Proc Natl Acad Sci USA 94:8191-8195.

Takahashi Y, Nakajima Y, Sakamoto T (1994) Dermatome mapping in the hindlimb by electrical stimulation of the spinal nerves. Neurosci Lett 168:85-88.

Theodosiou M, Rush RA, Zhou XF, Hu D, Walker JS, Tracey DJ (1999) Hyperalgesia due to nerve damage: role of nerve growth factor. Pain 81:245-255.

Thompson SW, Bennett DL, Kerr BJ, Bradbury EJ, McMahon SB (1999) Brain-derived neurotrophic factor is an endogenous modulator of no- ciceptive responses in the spinal cord. Proc Natl Acad Sci USA 96:7714-7718.

Wetmore C, Ernfors P, Persson H, Olson L (1990) Localization of brain-derived neurotrophic factor mRNA to neurons in the brain by in situ hybridization. Exp Neurol 109:141-152.

Whittemore SR, Friedman PL, Larhammar D, Persson H, Gonzalez CM, Holets VR (1988) Rat $\beta$-nerve growth factor sequence and site of synthesis in the adult hippocampus. J Neurosci Res 20:403-410.

Wright DE, Snider WD (1995) Neurotrophin receptor mRNA expression defines distinct populations of neurons in rat dorsal root ganglia. J Comp Neurol 351:329-338.

Zhou XF, Rush RA (1996) Endogenous brain-derived neurotrophic factor is anterogradely transported in primary sensory neurons. Neuroscience 74:945-951.

Zhou XF, Deng YS, Xian CJ, Zhong JH (2000) Neurotrophins from dorsal root ganglia trigger allodynia after spinal nerve injury in rats. Eur J Neurosci 12:100-105. 